\title{
Risk for developing Type 1 (insulin-dependent) diabetes mellitus and the presence of islet $64 \mathrm{~K}$ antibodies
}

\author{
H. Bärmeier ${ }^{1}$, D. K.McCulloch ${ }^{1,2}$, J.L.Neifing ${ }^{1,2}$, G. Warnock ${ }^{3}$, R. V.Rajotte ${ }^{3}$, J.P.Palmer ${ }^{1,2}$ and Å. Lernmark $^{1}$ \\ 1 Department of Medicine, University of Washington, Seattle, ${ }^{2}$ Veterans Administration Medical Center, Seattle, Washington, USA, and \\ ${ }^{3}$ Surgical-Medical-Research Unit, University of Alberta, Edmonton, Canada
}

\begin{abstract}
Summary. First-degree relatives of Type 1 (insulin-dependent) diabetic patients are at increased risk for developing clinical diabetes. The presence of islet cell or insulin autoantibodies further identifies relatives at greater risk, but not all immunologic-marker-positive relatives progress to disease. Beta-cell dysfunction, however, seems to be more prevalent than clinical Type 1 diabetes, since stable subclinical pancreatic Beta-cell dysfunction may occur. Antibodies against a $M_{r} 64,000(64 \mathrm{~K})$ islet Beta-cell protein, identified as glutamic acid decarboxylase, have been reported both at and several years prior to the clinical onset of Type 1 diabetes. We measured $64 \mathrm{~K}$ antibodies in first-degree relatives with varying degrees of Beta-cell dysfunction and risk for subsequent Type 1 diabetes to determine whether $64 \mathrm{~K}$ antibodies improve the predictive power of islet cell antibodies and/or insulin autoantibodies. In the Seattle Family Study first-degree relatives of Type 1 diabetic patients are followed prospectively using detailed Beta-cell function tests, insulin sensitivity, quantitative evaluation of islet cell antibodies and fluid phase assay insulin autoantibodies. $64 \mathrm{~K}$ antibodies were measured using dog islets. Relatives were selected, based on Beta-cell function to represent individuals at high
\end{abstract}

$(n=6)$ and low $(n=30)$ risk for subsequent Type 1 diabetes. The 30 low-risk individuals followed-up for 78 months, had stable Beta-cell function, and six (20\%) were negative for all autoantibodies, ten (33\%) were positive for insulin autoantibodies, $16(53 \%)$ were islet cell antibody positive while six $(20 \%)$ were positive for $64 \mathrm{~K}$ antibodies. In contrast, of the six subjects with progressively declining Beta-cell function who are therefore at high risk, two of whom have already developed Type 1 diabetes, two (33\%) were positive for insulin autoantibodies, four ( $67 \%$ ) were islet cell antibody positive, while all six $(100 \%)$ were positive for $64 \mathrm{~K}$ antibodies. We conclude that antibodies to the $\mathrm{M}_{\mathrm{r}} 64,000$ islet protein correlate with progressive Beta-cell dysfunction more closely than either islet cell antibodies or insulin autoantibodies, but can sometimes be present in individuals whose Beta-cell function remains stable over several years.

Key words: Type 1 (insulin-dependent) diabetes mellitus, insulin autoantibodies, islet cell antibodies, glutamic acid decarboxylase antibodies, intravenous glucose tolerance test, prediabetes.
An immunological pathogenesis for Type 1 (insulin-dependent) diabetes mellitus is supported by the presence of inflammatory cells in the islets of Langerhans at onset [1-3] and of autoantibodies, reacting with pancreatic islet cells [4-6], insulin [7], or a Beta-cell $\mathrm{M}_{\mathrm{r}} 64,000(64 \mathrm{~K})$ protein [8], as early as several years prior to clinical onset [9-12].

Prediction of future Type 1 diabetes, however, has been hampered by low sensitivity and specificity of conventional risk markers, such as islet cell antibodies (ICA), insulin autoantibodies (IAA) or certain human leucocyte antigen (HLA) specificities. A better predictive value may be obtained if several markers are combined $[13,14]$.

Since $64 \mathrm{~K}$ antibodies are detected at a high frequency in new onset Type 1 diabetic patients $[13,15,16]$ and may precede clinical onset by several years $[12,13]$, we addressed their relation to other markers in individuals at risk for Type 1 diabetes. Recently, evidence was presented that the $64 \mathrm{~K}$ antigen is glutamic acid decarboxylase (GAD) [17] present mostly in brain cells but also in pancreatic Beta cells [18]. The islet $64 \mathrm{~K}$ antigen is detected by immunoprecipitation of metabolically labelled islet preparations of a variety of different species $[8,15,19]$. In the present study, we analysed $64 \mathrm{~K}$ antibodies in a quantitative assay using dog islets.

We asked whether $64 \mathrm{~K}$ antibodies could distinguish between subgroups of first-degree relatives of Type 1 diabetic patients followed in the Seattle Family Study [20]. Four groups of first-degree relatives were defined based primarily on whether pancreatic Beta-cell function 
Table 1. Clinical information on first-degree relatives

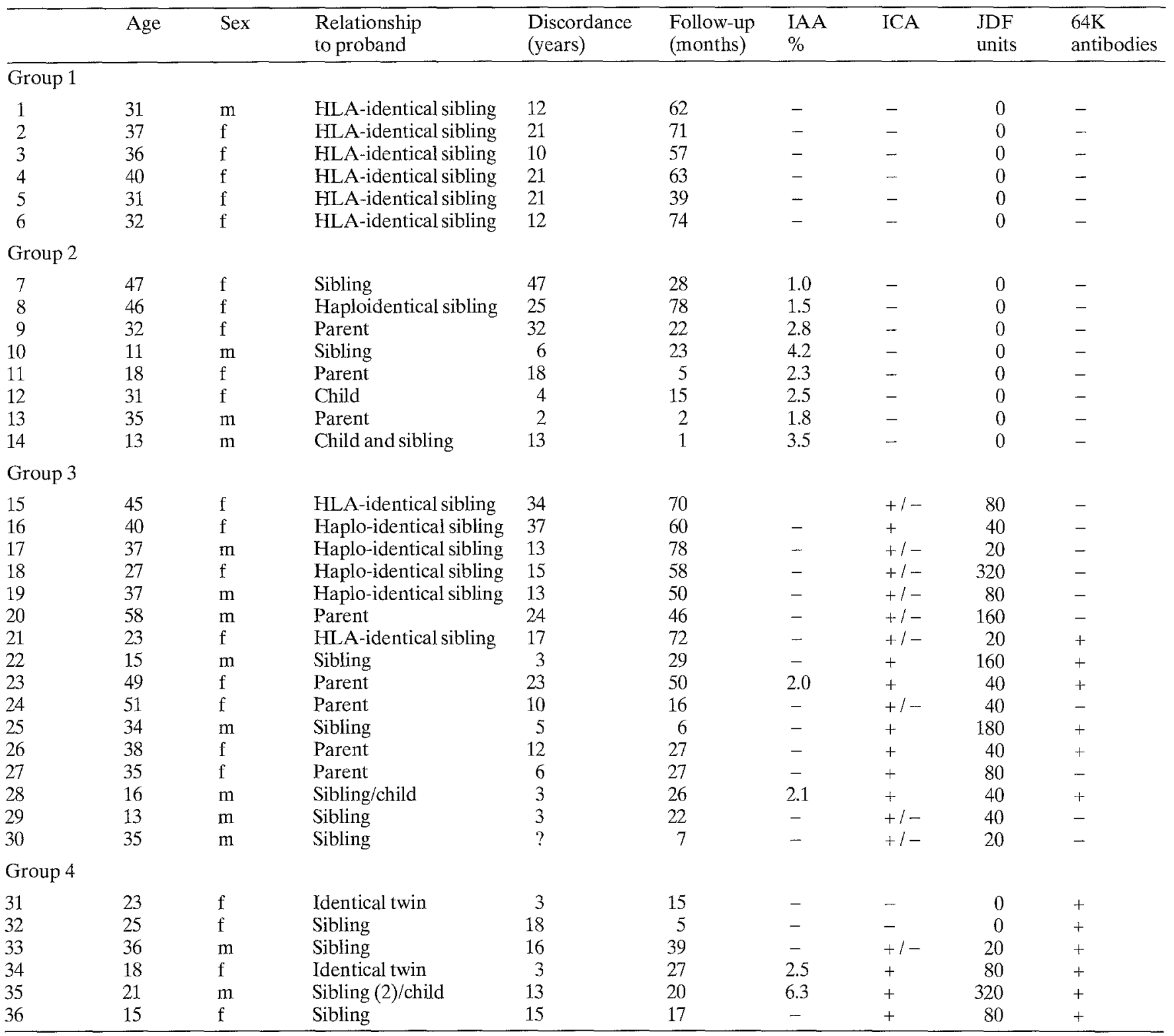

The insulin autoantibody (IAA) value (\% binding) shown is at the last follow-up. Islet cell antibodies (ICA) are indicated as negative $(-)$, positive $(+)$ or transient $(+/-)$. The highest ICA levels are

was stable or was progressively declining. Those with stable Beta-cell function were subdivided, depending on the presence or absence of IAA or ICA. The relationship of $64 \mathrm{~K}$ antibodies to these subgroups was then determined.

\section{Subjects and methods}

\section{Subjects}

All 36 subjects were first-degree relatives of Type 1 diabetic probands and were part of the prospective Seattle Family Study [20]. They were divided based on their pancreatic Beta-cell function (methodology described in detail below) into two main groups. The first had stable Beta-cell function $(n=30)$ since their acute insulin shown in Juvenile Diabetes Foundation (JDF) units and 64K antibodies as positive $(+)$ or negative $(-)$

response to glucose (AIRgluc) was greater than $50 \%$ of that expected at entry to the study, at all subsequent timepoints, and declined by less than $15 \%$ during follow-up. These subjects were further divided into HLA identical siblings who were negative for both ICA and IAA (Group $1, n=6$ ), relatives who were IAA positive only (Group 2, $n=8$ ) and those who were ICA positive (Group 3, $n=16$ ). Relatives with progressively impaired Beta-cell function (Group 4, $n=6$ ) had AIRgluc less than 50\% of that expected either at entry or at all subsequent timepoints, and showed decline of over $20 \%$ during follow-up. Clinical information on all subjects is given in Table 1. Beta-cell function (first and last timepoints) is shown in Figure 1.

\section{Beta-cell function tests}

Tests of Beta-cell function were carried out on two separate days for each subject. The methodology has been described in detail elsewhere $[20,21]$. Briefly, following an overnight fast a modified 


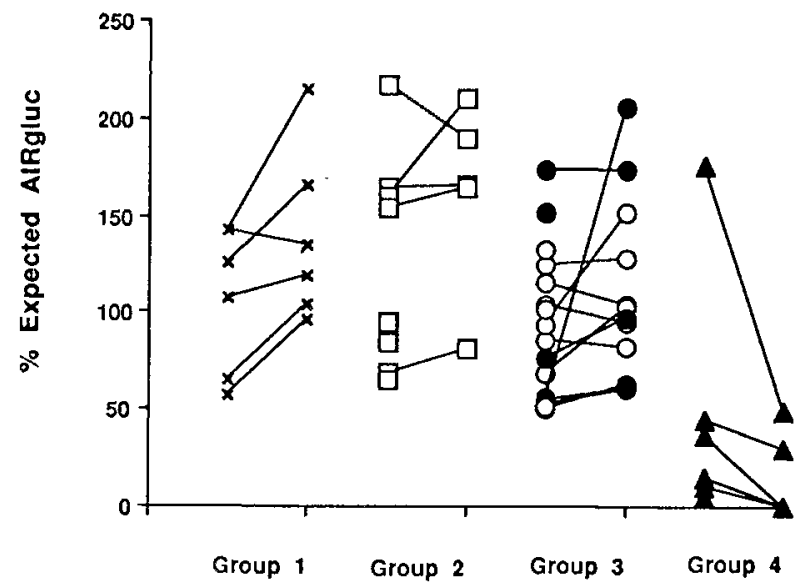

Fig. 1. Beta-cell function data from Groups 1-4. The \% expected acute insulin reponse to intravenous glucose $\left(\mathrm{AIR}_{\mathrm{gluc}}\right)$ at entry and at the most recent timepoint of the study are plotted for each group. Crosses depict Group 1, squares Group 2; circles Group 3, and triangles Group 4. Follow-up times were, for Group 1 39-74 months, Group 2 1-78 months, Group 3 6-78 months and Group 4 539 months. Filled symbols identify subjects who are $64 \mathrm{~K}$-antibody positive

intravenous glucose tolerance test (IVGTT) was performed to determine the acute insulin response to intravenous glucose (AIGgluc) calculated as the mean rise above baseline in circulating insulin during the first 10 min following i.v. glucose. Bergman's minimal model $[22,23]$ was applied to obtain the insulin sensitivity index (Si). The inverse relationship between $\mathrm{Si}$ and $\mathrm{AIR}_{\text {gluc }}$ among a normal non-diabetic population [21] allows us to express each subject's actual $\mathrm{AIR}_{\text {oluc }}$ as a percentage of the expected value (\% expected $A I R_{\text {gluc }}$ ) based on insulin sensitivity. This allows interpretation of Beta-cell function over time in relation to changes in insulin sensitivity. The mean percentage expected $A \mathrm{IR}_{\mathrm{gluc}}$ for non-diabetic individuals is 100 . Among a group of 18 non-diabetic control subjects studied on two occasions separated by an average of 13 months, the intra-individual coefficient of variation for expected AIR $_{\text {gluc }}$ was $10.5 \%$.

\section{$64 K$ antibody analysis}

Dog islets were isolated as previously detailed [24,25]. Metabolic labelling was done in batches of $10,000-15,000$ dog islets for $6 \mathrm{~h}$ at $37^{\circ} \mathrm{C}$ in L-methionine free RPMI 1640 with $0.5 \%$ (volume/volume) newborn calf serum (Gibco, Grand Island, N. Y. USA), $20 \mathrm{mmol} / \mathrm{l} \mathrm{glu-}$ cose, $20 \mathrm{mmol} / \mathrm{l}$ Hepes, $24 \mathrm{mmol} / \mathrm{NaHCO}, 100 \mathrm{U} / \mathrm{ml}$ penicillin and $100 \mu \mathrm{g} / \mathrm{ml}$ streptomycin (Gibco) supplemented with $1 \mathrm{mCi}^{35} \mathrm{~S}$-methionine (Amersham Inc., Arlington Heights, Ill., USA). Islets were homogenized in $10 \mathrm{mmol} / \mathrm{l}$ Hepes ( $\mathrm{pH} 7.4$ ) containing $0.25 \mathrm{~mol} / 1$ sucrose, $0.5 \%$ (weight/volume) aprotinin (Novo, Bagsvaerd, Denmark), $10 \mathrm{mmol} / 1$ benzamidine- $\mathrm{HCl}$ and $0.1 \mathrm{mmol} / \mathrm{p}$-chloromercuribenzenesulphonic acid per batch of islets, followed by centrifugation at $12,000 \times \mathrm{g}$ for $30 \mathrm{~min}$. The pellet was extracted using $10 \mathrm{mmol} / \mathrm{l}$ Hepes (pH 7.4), $150 \mathrm{mmol} / \mathrm{l} \mathrm{NaCl}, 10 \mathrm{mmol} / 1$ benzamidine- $\mathrm{HCl}, 0.5 \%$ (weight/volume) aprotinin and $2 \%$ Triton $\mathrm{X}-114$. Subsequent temperature-dependent phase separation [26] yielded a detergent-rich pellet. To decrease non-specific binding, this pellet was precleared by incubation with normal human serum followed by Protein A-Sepharose (LKB Bio Technology, Piscataway, N.J., USA). The precleared material was used for the Protein A-Sepharose facilitated immunoprecipitation with $15 \mu \mathrm{l}$ of serum from each individual. A standard $64 \mathrm{~K}$ antibody-positive serum which is also the Juvenile Diabetes Foundation (JDF) reference serum for ICA detection [27] and a $64 \mathrm{~K}$ antibody-negative control serum (from a healthy ICA-negative individual) were run in parallel and included on every gel as internal controls. Immune complexes were eluted by boiling and analysed on discontinuous $8 \%$ SDS-polyacrylamide gels under reducing conditions [28]. After staining and destaining, the gels were processed for fluorography with Amplify (Amersham). Dried gels were exposed to Kodak X-omat AR films (Kodak Company, Rochester, N. Y., USA) at $-80^{\circ} \mathrm{C}$.

The $64 \mathrm{~K}$ antibodies were determined in all 36 individuals by analysing blind the entire set of follow-up samples from every individual on the same gel. The presence or absence of a $64 \mathrm{~K}$ band was first scored visually on coded fluorograms. Only the positions of the positive or negative reference sera were revealed to the observer. Other bands present on the gels were not scored since they represented non-specific binding (Fig. 2). The fluorograms were therefore also analysed by densitometry using an LKB Ultroscan LX to express the results as a 64K Index [19]. A 64K Index of $0.29(\mathrm{x}+2 \mathrm{SD}$ of a panel of 20 normal healthy control subjects) was shown to separate visually rated $64 \mathrm{~K}$-antibody positive from negative sera. Dilution of the positive control serum showed a linear relationship between the amount of serum used and the 64K Index. The inter-assay coefficient of variation (cv) was $12.3 \%$; the intra-assay cv for duplicate determinations was $5.6 \%$.

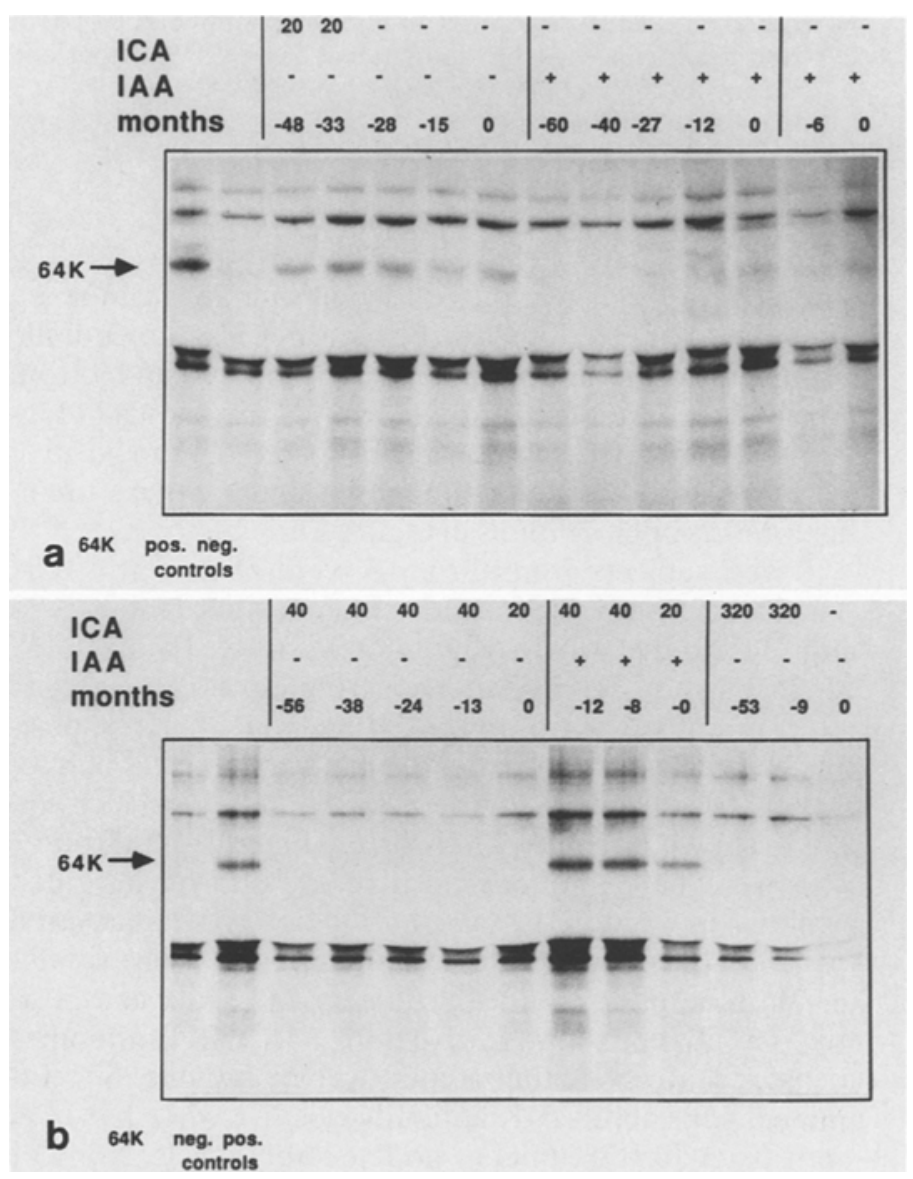

Fig. 2a,b. Fluorograms of immunoprecipitations to detect $64 \mathrm{~K}$-antibody positive sera. In panel A the follow-up samples from one Group 3 sibling (relative 21 in Table 1) (far left) is shown together with two relatives ( 8 and 9 , respectively) from Group 2 . The most recent timepoint ( 0 months) is shown on the right. Islet cell antibody (ICA) are indicated in Juvenile Diabetes Foundation units if positive. Insulin autoantibodies (IAA) are indicated as positive $(+)$ or negative $(-)$. The $64 \mathrm{~K}$-antibody positive and negative controls are shown in the first two lanes. In panel B samples in Group 3 (siblings 16, far left, 28 and 18) are shown. Antibodies against the $64 \mathrm{~K}$ protein were detected in subjects 21 and 28 


\section{Islet cell antibody assay}

An indirect immunofluorescence assay was used to determine endpoint titres of ICA. All sera were absorbed. with rat liver powder. Sections of snap-frozen, blood-group 0 human pancreas were incubated with serum in doubling dilutions. Washing in phosphate-buffered $150 \mathrm{mmol} / 1 \mathrm{NaCl}$ was followed by addition of fluorescein isothiocyanate-conjugated goat anti-human IgG (Sigma, St.Louis, Mo., USA). All samples, including a positive and negative control in each assay, were evaluated blind by two independent observers. ICA were considered to be present if fluorescence was detected by both observers in two separate assays. The results were expressed in Juvenile Diabetes Foundation (JDF) units [27] using the international JDF reference serum as standard. For evaluation of changes in ICA status in the individuals followed prospectively, the end-point titre was determined at all time points for that individual in the same assay. The lower detection limit for our assay was $10 \mathrm{JDF}$ units.

\section{Insulin autoantibody assay}

IAA were measured using an RIA as previously described [7, 29] and displacement with cold insulin as stipulated by the International Workshop on Standardization of Insulin Autoantibodies [30]. Our laboratory participates in the International Diabetes Workshop and proficiency-testing programs for both ICA and IAA.

\section{Results}

The $64 \mathrm{~K}$ antibodies in the follow-up samples from every individual were analysed on the same gel. Examples of the gels are shown in Figure $2 a$ and $b$. Subjects 8 and 9 from Group 2, persistently positive for IAA, are shown in Figure $2 \mathrm{a}$. None of the subjects in Groups 1 or 2 were positive for $64 \mathrm{~K}$ antibodies at any timepoints and are therefore illustrated as open symbols in Figure 3 a.

Seven subjects from Group 3 were persistently ICA positive, of whom two were also IAA positive (subjects 23 and 28 ) and five were $64 \mathrm{~K}$ antibody-positive (subjects 22 , $23,25,26$ and 28). Nine subjects from Group 3 were only intermittently ICA positive, of whom none was IAA positive but one was $64 \mathrm{~K}$ antibody-positive (subject 21). Subject 21 is illustrated in Figure 2a, while subjects 16, 18 and 28 are shown in Figure 2 b. All six subjects from Group 3 who were $64 \mathrm{~K}$ antibody-positive are shown as filled symbols in Figure $3 \mathrm{~b}$. 64K antibodies were measured on 23 occasions during follow-up of 6-68 (median 21) months in these six subjects and remained positive on all occasions. Subject 21 had $64 \mathrm{~K}$ antibodies measured at seven timepoints over 68 months. She remained persistently $64 \mathrm{~K}$ antibody-positive while her ICA went from 20 JDF units to undetectable levels. None of the subjects in Groups 1-3 have developed Type 1 diabetes.

Of the six subjects in Group 4, three were persistently ICA positive, of whom two were also IAA positive, one was intermittently ICA positive while two were both ICA and IAA negative. However, all six were $64 \mathrm{~K}$ antibodypositive on at least one timepoint. Subject 31 was $64 \mathrm{~K}$ antibody-negative on entry to the study but was $64 \mathrm{~K}$ antibody-positive at her most recent timepoint. Subject 33 has gone from being $64 \mathrm{~K}$ antibody-positive to negative while
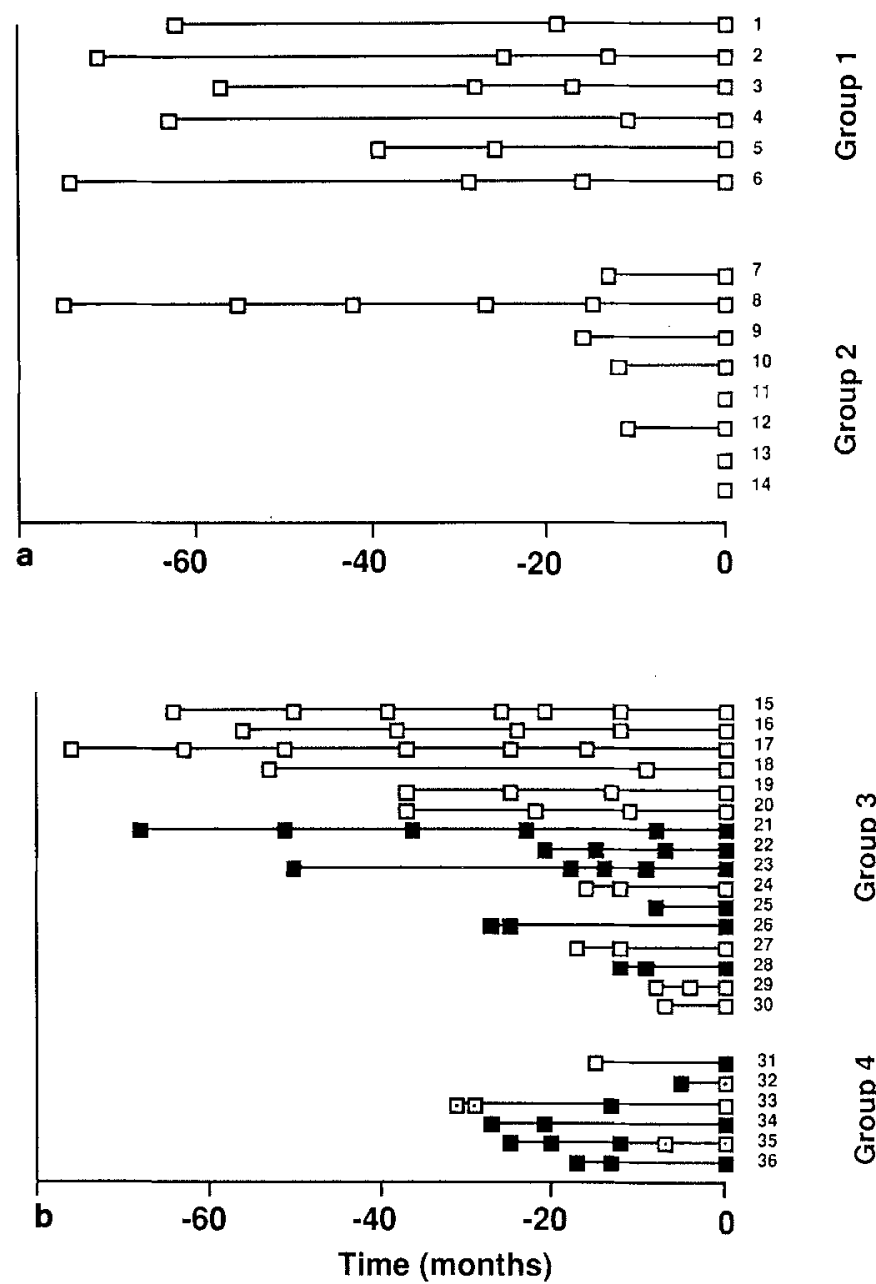

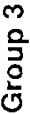

Fig. 3a,b. Presence of $64 \mathrm{~K}$ antibodies in first-degree relatives in Groups 1-2 (panel A) and 3-4 (panel B). Individual subjects as detailed in Table 1 , are plotted separately. Time in months with the most recent timepoint being 0 months is shown on the horizontal axis. 64K-antibody positive samples are depicted as filled squares, 64K-antibody negative samples as open squares. Timepoints for which $64 \mathrm{~K}$ antibodies' data are not available are depicted as open squares with a dot in the centre

subjects $32,34,35$ and 36 have been $64 \mathrm{~K}$ antibody-positive at all timepoints tested. Subjects 31 and 34 have developed clinical Type 1 diabetes about 12 months after their last timepoint.

\section{Discussion}

Detailed follow-up studies in relatives of Type 1 diabetic patients have shown that subclinical states of Beta-cell dysfunction that remain stable can occur among ICApositive relatives as well as monozygotic twins of Type 1 diabetic patients $[20,34]$ without progression to clinical diabetes. The spectrum of Beta-cell dysfunction ranging from subtle changes to clinical diabetes may include an unknown percentage of individuals with stable subclinical Beta-cell dysfunction who are not progressing to clinical Type 1 diabetes. It is therefore critical to distinguish individuals with progressively impaired Beta-cell function from individuals with stable Beta-cell function in order to 
assess their risk for future clinical Type 1 diabetes. In this study we have subdivided relatives based on the results of prospective Beta-cell function testing and have then examined the antibody status within subgroups. $64 \mathrm{~K}$ antibodies were present in all subjects with progressively impaired Beta-cell function, including two subjects who were negative for both ICA and IAA. However, $64 \mathrm{~K}$ antibodies were present in only $20 \%$ of those whose Beta-cell function was stable. Thus, the presence of $64 \mathrm{~K}$ antibodies appears to be a better marker for disease progression than either ICA or IAA. However, the fact that $64 \mathrm{~K}$ antibodies can be found in some subjects who are at relatively low risk for future clinical Type 1 diabetes is interesting. Three of the subjects in Group 3 who were positive for $64 \mathrm{~K}$ antibodies over several years (subjects 21, 23 and 26) are adults who have already been discordant for at least 12 years. During follow-up of up to 6 years there is no evidence of progressive decline in Beta-cell function and so the risk of clinical diabetes developing in these individuals is probably low. These data therefore suggest that the presence of $64 \mathrm{~K}$ antibodies does not always predict subsequent clinical Type 1 diabetes.

It is clear that no single genetic or immunologic marker yet identified can completely distinguish those subjects with progressive from those with stable Beta-cell dysfunction, although many are helpful, especially when found in combination. An increased risk for Type 1 diabetes is associated with certain haplotypes of the HLA class II DR and DQ specificities [31]. However, these specificities, although necessary, are not sufficient since monozygotic twins are only $30-50 \%$ concordant for the disease [32-34]. Siblings of a Type 1 diabetic patient have a $16-30 \%$ risk of developing clinical Type 1 diabetes by the age of 30 years if they are HLA identical, but have only a 5\% risk if they are haploidentical [35-37]. However, due to this genetic risk, family studies following relatives of Type 1 diabetic patients provide a unique opportunity to develop possible risk markers and to investigate their predictive value.

Islet cell antibodies (ICA) have been found in 3-21\% of first-degree relatives of Type 1 diabetic patients [35, $38]$, but also in as many as $2-4 \%$ of the general population $[39,40]$. ICA-positive individuals therefore outnumber those eventually developing clinical Type 1 diabetes, since the prevalence of Type 1 diabetes in the general population is $0.15-0.3 \%[41,42]$. Furthermore, ICA levels may fluctuate or be only transiently high [46], and they correlate poorly with Beta-cell function [43]. IAA, even though detectable in some patients before onset are strongly correlated with age but poorly associated with Beta-cell dysfunction or future Type 1 diabetes in ICA-negative individuals $[43,44]$. Individuals with not only high titre ICA but also IAA and/or a decrease in first-phase insulin response have been reported to be at higher risk for Type 1 diabetes $[14,45,46]$. A large study on ICA in first-degree relatives showed that ICA-positive relatives in multiplex families are at a higher risk for developing Type 1 diabetes than relatives of simplex families [47]. Our finding that $64 \mathrm{~K}$ antibodies correlate with progressively impaired Beta-cell function and high risk for Type 1 diabetes suggests that $64 \mathrm{~K}$ antibodies may be a more specific marker for autoimmune processes leading to Type 1 diabetes than ICA and/or IAA.

The role of $64 \mathrm{~K}$ antibodies in the disease process of Type 1 diabetes has yet to be clarified. They were detected in selected individuals up to 8 years prior to onset [12] with high frequency at onset $[15,19]$ and prolonged persistence after onset [48]. The $64 \mathrm{~K}$ antibodies were also detected in sera from diabetic BB rats [49] and non-obese diabetic (NOD) mice [50] as early as the time of weaning. Thus, $64 \mathrm{~K}$ antibodies are present early in the pathogenesis not only of human Type 1 diabetes but also in autoimmune diabetic syndromes in rodents.

More recently the finding of $64 \mathrm{~K}$ antibodies before the onset of clinical Type 1 diabetes was confirmed in a group of 28 pre-diabetic patients [13] also demonstrating the presence of $64 \mathrm{~K}$ antibodies in first-degree relatives associated with both ICA ( $\geq 20$ JDF units) and IAA, which is in agreement with our data. In contrast to our finding, four of five individuals, who were positive for IAA only, had $64 \mathrm{~K}$ antibodies. However, they were all younger than 5 years of age and such individuals were not included in our study. IAA are present at higher frequencies in this age group $[51,52]$. In newly diagnosed diabetic patients no effect of age on $64 \mathrm{~K}$-antibody frequencies was detected in patients aged $0-34$ years $[15,19]$. Furthermore, in our prospective study we identified individuals with fluctuating or disappearing ICA who, nevertheless, were $64 \mathrm{~K}$ antibody positive. Thus, $64 \mathrm{~K}$ antibodies were not restricted to ICApositive individuals with titres $\geq 20 \mathrm{JDF}$ units [13]. It should be noted that the age of the subjects and length of discordance in Group 4 are not significantly lower than the other groups.

Quantitation of $64 \mathrm{~K}$ antibodies should eventually aid understanding of the natural history of these antibodies in Type 1 diabetes. In this study we determined $64 \mathrm{~K}$-antibody positivity using a quantitative $64 \mathrm{~K}$ Index. The identification of the $64 \mathrm{~K}$ protein as glutamic acid decarboxylase [17] should permit further refinement in the quantitative analysis of these antibodies in subjects at risk for developing Type 1 diabetes. The 64K Index [19] is however currently the most powerful way to obtain objective and quantitative $64 \mathrm{~K}$-antibody levels. In this assay system a positive and negative reference serum are used to compute the $64 \mathrm{~K}$ Index based on densitometric scanning of fluorograms, thus minimizing inter-assay variation and allowing analysis of changes in $64 \mathrm{~K}$-antibody levels.

It is obviously necessary to be cautious when interpreting prospective data such as those in our study. We cannot say with certainty that the remaining four individuals in Group 4 will develop clinical Type 1 diabetes in the future (although two have already done so), or that none of those in Groups 1, 2 and 3 will do so. However, a prospective evaluation of the end-organ being attacked (the pancreatic Beta-cell) would seem to be the most informative way to evaluate the pre-clinical period. It is clear that Type 1 diabetes is not a disease restricted to childhood, but rather one affecting people of all ages, with wide variation in the spectrum of disease activity and rate of progression. We conclude that $64 \mathrm{~K}$ antibodies reflect progressively impaired Beta-cell function better than ICA or IAA and therefore are useful in the follow-up of individuals at risk 
for Type 1 diabetes. Their measurement, in combination with other clinical data, may eventually lead to the identification of the individuals at highest risk such that preventive treatment may be administered before a significant loss of Beta cells induces insulin dependence and clinical onset of the disease.

Acknowledgements. This work was supported by National Institutes of Health grants DK-26160, DK-33873, DK-41801 and DK-17047. $\mathrm{H}$. B. is the recipient of a fellowship from the Deutsche Forschungsgemeinschaft. We wish to thank Ms. S. Blaylock for secretarial assistance and Ms. R. Park and M. McCulloch for technical assistance. We also thank LKB, Piscataway, N.J., USA, for a generous gift of Protein A-Sepharose and Novo/Nordisk, Bagsvœrd, Denmark, for aprotinin. The results were presented in part at the American Diabetes Association meeting in Atlanta, June 19, 1990.

\section{References}

1. Gepts W (1965) Pathologic anatomy of the pancreas in juvenile diabetes mellitus. Diabetes 14: 619-633

2. Foulis AK, Stewart JA (1984) The pancreas in recent-onset Type 1 (insulin-dependent) diabetes mellitus: insulin content of islets, insulitis and associated changes in the exocrine acinar tissue. Diabetologia 26: 456-461

3. Klöppel G, Drenck CR, Oberholzer M, Heitz PU (1984) Morphometric evidence for a striking $\beta$-cell reduction at the clinical onset of Type 1 diabetes. Virchows Arch Pathol Anat 403: 441452

4. Bottazzo GF, Florin-Christensen A, Doniach D (1974) Islet cell antibodies in diabetes mellitus with autoimmune polyendocrine deficiencies. Lancet II: 1279-1283

5. MacCuish AC, Barnes EW, Irvine WJ, Duncan LJP (1974) Antibodies to pancreatic islet-cells in insulin-dependent diabetics with coexistent autoimmune disease. Lancet II: 1529-1531

6. Lernmark $\AA$, Freedman ZR, Hofmann C, Rubenstein AH, Steiner DF, Jackson RL, Winter RJ, Traisman HS (1978) Isletcell-surface antibodies in juvenile diabetes mellitus. $\mathrm{N}$ Engl $\mathbf{J}$ Med 299: 375-380

7. Palmer JP, Asplin CM, Clemons P, Lyen K, Tatpati O, Raghu PK, Paguette TL (1983) Insulin antibodies in insulin-dependent diabetics before insulin treatment. Science 222: 1337-1339

8. Baekkeskov S, Nielsen JH, Marner B, Bilde T, Ludvigsson J, Lernmark $\AA$ (1982) Autoantibodies in newly diagnosed diabetic children immunoprecipitate human pancreatic islet cell proteins. Nature 298: 167-169

9. Lendrum R, Walker G, Cudworth AG, Theophanides C, Pyke DA, Bloom A, Gamble DR (1976) Islet-cell antibody in diabetes mellitus. Lancet II: $1273-1276$

10. Gorsuch AN, Dean BM, Bottazzo GF, Lister J, Cudworth AG (1980) Evidence that type 1 diabetes and thyrogastric autoimmunity have different genetic determinants. Br Med J 1: 145-147

11. Srikanta S, Ricker AT, McCulloch DK, Soeldner JS, Eisenbarth GS, Palmer JP (1986) Autoimmunity to insulin, beta cell dysfunction, and development of insulin-dependent diabetes mellitus. Diabetes 35: 139-142

12. Baekkeskov S, Landin-Olsson M, Kristensen JK et al. (1987) Antibodies to a Mr 64,000 human islet cell antigen precede the clinical onset of insulin-dependent diabetes. J Clin Invest 79: 926-934

13. Atkinson MA, Maclaren NK, Scharp DW, Lacy PE, Riley WJ (1990) $64,000 \mathrm{M}_{\mathrm{r}}$ autoantibodies as predictors of insulin-dependent diabetes. Lancet 335: 1357-1360

14. Betterle C, Presotto F, Pedini B, Moro L, Slack RS, Zanette F, Zanchetta R (1987) Islet cell and insulin autoantibodies in organspecific autoimmune patients. Their behaviour and predictive value for the development of Type 1 (insulin-dependent) diabetes mellitus. A 10-year follow-up study. Diabetologia 30 : 292-297

15. Christie M, Landin-Olsson M, Sundkvist G, Dahlquist G, Lernmark $\AA$, Baekkeskov $S$ (1988) Antibodies to a $M_{r}-64000$ islet cell protein in Swedish children with newly diagnosed Type 1 (insulin-dependent) diabetes. Diabetologia 31: 597-602

16. Bärmeier H, McCulloch D, Neifing J, Rajotte R, Palmer J, Lernmark $\AA$ (1990) Progression of beta-cell dysfunction is associated with $64 \mathrm{~K}$ antibodies in first degree relatives of IDDM patients. Diabetes 39 [Suppl 1]: 122A (Abstract)

17. Baekkeskov S, Aanstoot HJ, Christgau S, Reetz A, Solimena M, Cascalho M, Folli F, Richter-Olesen H, DeCamilli P (1990) Identification of the $64 \mathrm{~K}$ autoantigen in insulin-dependent diabetes as the GABA-synthesizing enzyme glutamic acid decarboxylase. Nature 347: 151-156

18. Erdö SL, Wolff JR (1990) Gamma-aminobutyric acid outside the mammalian brain. J Neurochem 54: 363-372

19. Bärmeier H (1990) Species comparison of 64K antigen expression. Immunology of Diabetes, 10th International Workshop, Israel

20. McCulloch DK, Klaff LJ, Kahn SE et al. (1990) Nonprogression of subclinical $\beta$-cell dysfunction among first degree relatives of IDDM patients: 5-yr follow-up of the Seattle family study. Diabetes 39: 549-556

21. Johnston C, Raghu P, McCulloch D, Beard JC, Ward WK, Klaff LJ, McKight B, Bergman RN, Palmer JP (1987) $\beta$-cell function and insulin sensitivity in nondiabetic HLA-identical siblings of insulin-dependent diabetics. Diabetes 36: 829-837

22. Bergman RN, Ider YZ, Bowden CR, Cobelli C (1979) Quantitative estimation of insulin sensitivity. Am J Physiol 236: E667E677

23. Beard JC, Bergman RN, Ward WK, Porte D Jr (1986) The insulin sensitivity index in non-diabetic man: correlation between clamp derived and IVGTT derived values. Diabetes 35: 362-369

24. Warnock GL, Rajotte RV (1988) Critical mass of purified islets that induce normaglycaemia after implantation into dogs. Diabetes 37: 467-470

25. Warnock GL, Cattral MS, Rajotte RV (1988) Normoglycaemia after implantation of purified islet cells in dogs. Can J Surg 31: $421-426$

26. Bordier C (1981) Phase separation of integral membrane proteins in Triton X-114 solution. J Biol Chem 256: 1604-1607

27. Bonifacio E, Lernmark Å, Dawkins RL (1988) Serum exchange and use of dilutions have improved precision of measurement of islet cell antibodies. J Immunol Methods 106: 83-88

28. Laemmli UK (1970) Cleavage of structural proteins during the assembly of the head of bacteriophage. Nature 227:680-685

29. Palmer JP, Asplin CM, Raghu PK et al. (1986) Anti-insulin antibodies in insulin-dependent diabetics before insulin treatment a new marker for autoimmune $\beta$-cell damage? Pediatric Adolescent Endocrinol 15: 111-116

30. Palmer JP, Wilkin TJ, Kurtz AB, Bonifacio E (1990) The Third International Workshop on the Standardization of Insulin Antibody Measurement. Diabetologia 33: 60-61

31. Wassmuth R, Lernmark $\AA$ (1990) The genetics of susceptibility to diabetes. Clinical Immunology Immunopathology 53:358-399

32. Barnett AH, Eff C, Leslie RDG, Pyke DA (1981) Diabetes in identical twins: A study of 200 pairs. Diabetologia 20: 87-93

33. Pyke DA (1988) Development of diabetes in identical twins. Adv Exp Med Biol 246: 255-258

34. Kumar D, Gemayel NS, Gill SK, Bray GA, Roy-Burman P, Deapen D, Mack TM (1988) Type-specific concordance in young diabetic monozygotic twins. Adv Exp Med Biol 246: 259-267

35. Ginsberg-Fellner F, Dobersen MJ, Witt ME, Rayfield EJ, Rubenstein P, Notkins AL (1982) HLA antigen, cytoplasmic islet cell antibodies, and carbohydrate tolerance in families of children with insulin-dependent diabetes mellitus. Diabetes 31 : 292-297

36. Tillil H, Köbberling J (1987) Age-corrected empirical genetic risk estimates for first-degree relatives of IDDM patients. Diabetes 36: 93-99 
37. Tarn AC, Thomas JN, Dean BM, Ingram D, Schwarz G, Bottazzo GF, Gale EAM (1988) Predicting insulin-dependent diabetes. Lancet I: $845-850$

38. Lendrum R, Walker G, Gamble DR (1975) Islet-cell antibodies in juvenile diabetes mellitus of recent onset. Lancet I: 880-883

39. Bonifacio E, Bingley PJ, Shattock M, Dean BM, Dunger D, Gale EAM, Bottazzo GF (1990) Quantification of islet cell antibodies and prediction of insulin dependent diabetes. Lancet 335: 147149

40. Landin-Olsson M, Karlsson A, Dahlquist G, Blom L, Lernmark $\AA$, Sundkvist G (1989) Islet cell and other organ-specific autoantibodies in all children developing Type 1 (insulin-independent) diabetes mellitus in Sweden during one year and in matched control children. Diabetologia 32: 387-395

41. Dahlquist G, Blom L, Holmgren G, Hägglöf B, Larsson Y, Sterky $G$, Wall S (1985) The epidemiology of diabetes in Swedish children 0-14 years - A six-year prospective study. Diabetologia 28 : 802-808

42. Group DERI (1990) Secular trends in incidence of childhood IDDM in 10 countries. Diabetes 39: 858-864

43. Spencer KM, Tarn A, Dean BM, Lister J, Bottazzo GF (1984) Fluctuating islet-cell autoimmunity in unaffected relatives of patients with insulin-dependent diabetes. Lancet I: 764-766

44. Wilkin T, Armitage M, Casey C, Pyke DA, Hoskins PJ, Rodier M, Diaz JL, Leslie RDG (1985) Value of insulin autoantibodies as serum markers for insulin-dependent diabetes mellitus. Lancet I: $480-482$

45. Ginsberg-Fellner F, Witt ME, Franklin BH, Yagihashi S, Togushi Y, Dobersen MJ, Rubinstein P, Notkins AL (1985) Triad of markers for identifying children at high risk of developing insulin-dependent diabetes mellitus. JAMA 254: 1469-1470

46. Srikanta S, Ganda OP, Rabizadeh A, Soeldner JS, Eisenbarth GS (1985) First-degree relatives of patients with Type 1 diabetes mellitus. Islet-cell antibodies and abnormal insulin secretion. $\mathrm{N}$ Engl J Med 313: 462-464

47. Riley WJ, Maclaren NK, Krischer J et al. (1990) A prospective study of the development of diabetes in relatives of patients with insulin-dependent diabetes. N Engl J Med 323: 1167-1172

48. Christie M, Delovitch TL (1990) Persistence of antibodies to a $64,000-\mathrm{Mr}$ islet cell protein after onset of type 1 diabetes. Diabetes 39: 653-659

49. Baekkeskov S, Dyrberg T, Lernmark Å (1984) Autoantibodies to a 64-kilodalton islet cell protein precede the onset of spontaneous diabetes in the BB rat. Science 224: 1348-1350

50. Atkinson MA, Maclaren NK (1988) Autoantibodies in nonobese diabetic mice immunoprecipitate $64,000-\mathrm{Mr}$ islet antigen. Diabetes 37: 1587-1590

51. Arslanian SA, Becker DJ, Rabin B, Atchinson R, Eberhardt M, Cavender D, Dorman J, Drash AL (1985) Correlates of insulin antibodies in newly diagnosed children with insulin-dependent diabetes before insulin therapy. Diabetes 34: 926-930

52. McEvoy RC, Witt ME, Ginsberg-Fellner F, Rubenstein P (1986) Anti-insulin antibodies in children with Type I diabetes mellitus. Diabetes 35: 634-641

Received: 19 February 1991

and in revised form: 19 June 1991

Dr. Å. Lernmark

Department of Medicine, RG-20

University of Washington

Seattle WA 98195

USA 